\title{
Sclerotinia Rot of Hygrophila auriculata (Schum.) Heynne. in Lateritic Zone of West Bengal, India
}

\author{
Bholanath Mondal ${ }^{1 *}$, Papiya Debbarma ${ }^{1}$ and Dinesh Chandra Khatua ${ }^{2}$ \\ ${ }^{1}$ Dept. of Plant Protection, Institute of Agriculture, Visva-Bharati, Sriniketan, West Bengal (731 236), India \\ ${ }^{2}$ B7/305, Kalyani, Nadia, West Bengal (741 235), India
}

\section{Article History}

Manuscript No. AR1621

Received in $20^{\text {th }}$ June, 2016

Received in revised form $18^{\text {th }}$ September, 2016

Accepted in final form $4^{\text {th }}$ October, 2016

\section{Correspondence to}

*E-mail: bholanath.ppvb@gmail.com

\section{Keywords}

Ayurveda, kulekhara, Sclerotinia

sclerotiorum, white rot

\begin{abstract}
Sclerotinia rot of Kulekhara [Hygrophila auriculata (Schum.) Heynne.] caused by Sclerotinia sclerotiorum (Lib.) de Bary was recorded probably first time in a homestead gardens at Sriniketan (Birbhum district) under Lateritic-red agroclimatic zone of West Bengal, India during winter months of January-February, 2014 and 2015. Kulekhara is an Indian ayurvedic plant familiar for its medicinal value commonly used for increasing haemoglobin in blood. It is also used as vegetable in rural Bengal. S. sclerotiorum is one of the most devastating and cosmopolitan necrotrophic fungal plant pathogens having wide host range infects a numbers of economically important plants throughout the world. Initially water soaked lesions were produced on branches and leaves. Soon the affected area covered with white mycelial growth of the causal fungus. With progress of the disease, many plants died. Sclerotia formation was not found on the infected plants but more or less spherical large and black sclerotia were produced in soil at base of the infected plant. The pathogen did not show host specificity. PDA medium amended with chloramphenicol was used to isolate and maintain the pathogen. White mycelium with hyaline, branched and septate hyphae was produced by the pathogen on PDA medium. Black sclerotia near spherical in shape generally were formed within 4-6 days of incubation at $25^{\circ} \mathrm{C}$.
\end{abstract}

\section{Introduction}

Hygrophila auriculata (Schum.) Heynne. (Syn. Hygrophila spinosa T., Family Acanthaceae) is popularly known as Kulekhara. It is a leafy vegetables-cum-medicinal plant that usually grows in swampy ground in tropical and subtropical areas. Now a days, some people grow this plant in homestead garden. It is a stout herb with numerous fasciculate usually unbranched, subquadrangular, erect, stems, 0.6-1.5 m high, thickened at the nodes. Leaves are oblong-lanceolate or oblanceolate, sparsely hispid on both sides, six at a node, the outer 2 large, reaching $15 \mathrm{~cm}$ long, each leaf bear straight, sharp, yellow, spines in its axil. Flowers are purple-blue, 3.5 $\mathrm{cm}$ long, in a whorl of 8 at each node. Capsules are $8 \mathrm{~mm}$ long, linear-oblong, pointed. Leaves of the plants are commonly used for increasing haemoglobin in blood. In the swampy ground or homestead garden this plant grows as compact population. In the winter season of 2014 and 2015 (mainly the month of January-February), rotting of this plant was observed in homestead garden at Sriniketan (Birbhum district) under
Lateritic-red agro-climatic zone of West Bengal which created an interest to explore this incidence including of its host range and pathogenicity.

\section{Materials and Methods}

After observation of died Kulekhara plant in January, 2014 a survey was conducted throughout the winter season in the homestead gardens at Sriniketan (Birbhum district) under Lateritic-Red agroclimatic zone of West Bengal. Detailed symptoms were recorded. Infected plants were collected and brought to the laboratory for detailed investigation. The infected plants were incubated in polypropylene packet with water soaked cotton and the mouth of the packet was closed after blowing air into the packet to create humid condition. The pathogen was isolated on PDA medium amended with chloramphenicol by putting small piece of surface sterilized diseased tissue. Pure culture of the pathogen was maintained in PDA medium (Khatua et al., 2014a). General characteristics of the fungus were noted after growth on the media. Host range study was conducted by artificial inoculation (Khatua 
et al., 2014a). For host range study and pathogenicity test, mycelial strip from four days old culture prepared on PDA in petriplate was used as inoculum. Small incision $(0.5 \mathrm{~cm}$ length and $0.5-1.0 \mathrm{~mm}$ depth) was given on the branch of the plant at the internode and the mycelial strip was put on the injured tissue. Mycelial strip was then wrapped with thin layer of moist cotton. Water was sprayed on this branch and was covered with polythene bag to maintain humidity. Three days after inoculation the polythene bag was removed.

\section{Results and Discussion}

The disease was observed in the homestead garden situated at Sriniketan mainly during winter months of January-February, 2014 and 2015. Initially water soaked lesions were produced on branches and leaves. In humid condition the affected area covered with prominent white mycelial growth of the causal fungus. Rotting symptom was more prominent in young plants (Figure 1). As this plant grows as compact population, the disease spread rapidly. With progress of the disease, size of the lesion on the branches found increased and many more leaves were infected. Ultimately the infected plants died (Figure 1). Interestingly, sclerotia formation was not found on the infected plants but more or less spherical black sclerotia were produced on soil surface at base of infected plants.

The pathogen produced white mycelium with hyaline, branched and septate hyphae on PDA medium. Black sclerotia near spherical in shape generally were formed within 4-6 days of incubation at $25^{\circ} \mathrm{C}$ towards the periphery of the medium in petridish (Figure 2). The sclerotia were silvery white in the initial stage but turned dark with increasing age of the culture. On PDA the sclerotia were large and irregular with an average (average of ten sclerotia) size of $0.74 \times 0.40 \mathrm{~cm}^{2}$ and

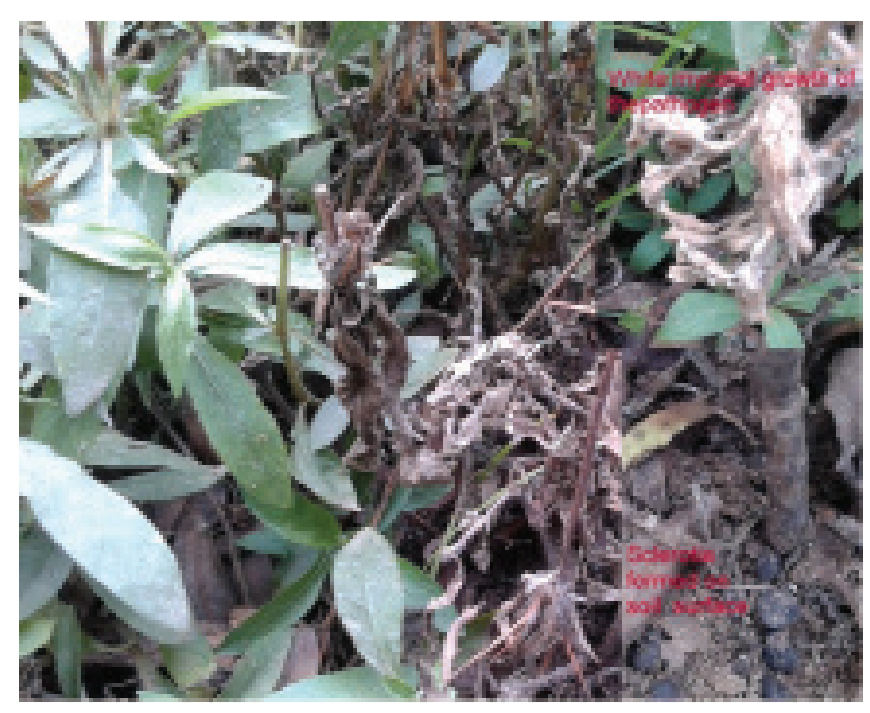

Figure 1: White rot infected Hygrophila auriculata plants and sclerotia at the base of the plant

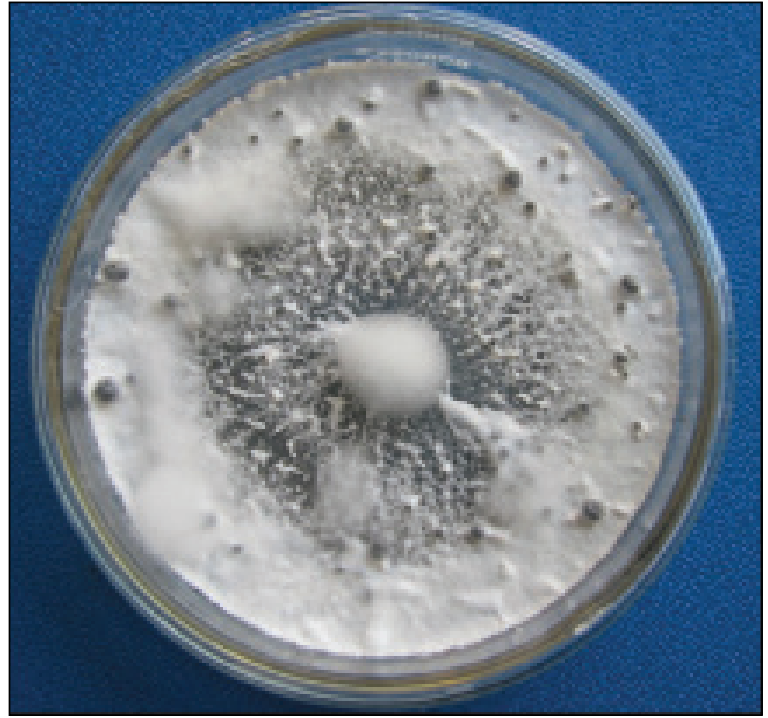

Figure 2: Whitish growth of S. sclerotiorum with formation of sclerotia in PDA medium

fresh weight of $0.240 \mathrm{~g}$. Based on the cultural characteristics the pathogen was identified as Sclerotinia sclerotiorum (Lib.) de Bary (Purdy, 1955; Khatua et al., 2014a; Khatua et al., 2014b; Hansda et al., 2014).

On pathogenicity test, symptoms of the disease appeared at 5 to 7 days after inoculation. On artificial inoculation isolate of Sclerotinia sclerotiorum from bean plant (Phaseolus vulgaris L.) could infect Phaseolus vulgaris, Hygrophila auriculata, Ocimum sanctum and Centella asiatica. Similarly isolate of this pathogen from Hygrophila auriculata infected Phaseolus vulgaris, Hygrophila auriculata, Ocimum sanctum and Centella asiatica indicating the pathogen did not have host specificity (Table 1). The findings are corroborated with the earlier workers (Khatua et al., 2014a).

Sclerotinia rot of medicinal plants viz. Ocimum sanctum L. (Khatua et al., 2014a), Psoralea corylifolia L. (Mondal et al., 2014), Centella asiatica (L.) Urb. (Mondal and Khatua, 2015) and Enhydra fluctuans Lour. (Mondal et al., 2015) was reported earlier from West Bengal but the leafy vegetablecum-medicinal plant, Hygrophila auriculata appears to be a new host for Sclerotinia sclerotiorum.

Table 1: Pathogenicity of different isolates of S. Sclerotiorum

\begin{tabular}{lcccc}
\hline \multirow{2}{*}{$\begin{array}{l}\text { Sources of isolates } \\
\text { of S. Sclerotiorum }\end{array}$} & \multicolumn{5}{c}{ Disease reaction on } \\
\cline { 2 - 5 } & PV & HA & OS & CA \\
\hline Phaseolus vulgaris & ++ & ++ & ++ & ++ \\
Hygrophila auriculata & ++ & ++ & ++ & ++ \\
\hline
\end{tabular}

PV: Phaseolus vulgaris; HA: Hygrophila auriculata; OS:

Ocimum sanctum; CA: Centella asiatica; ++=production of symptoms with profuse mycelia growth 


\section{Conclusion}

The disease is becoming a serious threat to different economically important vegetable crops as well as medicinal plants grown in homestead garden. Probably the disease is spreading rapidly in homestead garden from the thrown out infected and rotten vegetables purchased from market that are unsuitable to cook. Care should be taken to destroy these rotten vegetables; otherwise it will be a major disease in near future under the changed climatic conditions.

\section{References}

Hansda, S., Ray, S. K., Dutta, S., Khatua, D. C., 2014. Sclerotinia rot in West Bengal. Journal of Mycopathological Research 52(2), 273-278.

Khatua, D.C., Mondal, B., Hansda, S., 2014b. White rot of Coreopsis drummondii-a new record from West Bengal, India. Journal of Mycopathological Research 52(1), 157-158.
Khatua, D.C., Pauraia, N., Mondal, B., 2014a. Sclerotinia rot of Ocimum sanctum and the host range of the pathogen. International Journal of Agriculture, Environment \& Biotechnology 7(3), 651-656.

Mondal, B., Khatua, D. C., 2015. White rot of Centella asiatica and two weeds in West Bengal, India. Journal of Crop and Weed 11(1), 225-226.

Mondal, B., Khatua, D.C., Hansda, S., Sharma, R., 2015. Addition to the host range of Sclerotinia sclerotiorum in West Bengal. Scholars Academic Journal of Biosciences 3(4), 361-364.

Mondal, B., Mahapatra, S., Khatua, D.C., 2014. Records of some new diseases of horticultural plants of West Bengal. Journal of Interacademicia 16(1), 36-43.

Purdy, L.H., 1955. A broader concept of the species of Sclerotinia sclerotiorum based on the variability. Phytopathology 45, 421-427. 